Original Research Article

\title{
Cost comparisons of five leading brands of the antihypertensive drug, Telmisartan, available in an Indian city
}

\author{
Vikram A. Rajadnya ${ }^{1 *}$, Sheena R. Bedi ${ }^{2}$
}

${ }^{1}$ Department of Pharmacology, ${ }^{2}$ Student, D.Y. Patil Medical College, Kolhapur, Maharashtra, India

Received: 09 April 2019 Accepted: 07 May 2019

*Correspondence to: Dr. Vikram A. Rajadnya, Email: sportsdocind@ rediffmail.com

Copyright: (C) the author(s), publisher and licensee Medip Academy. This is an openaccess article distributed under the terms of the Creative Commons Attribution NonCommercial License, which permits unrestricted noncommercial use, distribution, and reproduction in any medium, provided the original work is properly cited.

\begin{abstract}
Background: Antihypertensive drugs have to be taken lifelong, after initiation of the treatment. Price variation can lead to huge economic burden on the patients of hypertension, especially when cost considerations are not undertaken by the prescribing physician. This study was undertaken to compare the annual cost, to the patient, of five different most commonly prescribed brands of Telmisartan $40 \mathrm{mg}$, in Kolhapur city.

Methods: Authors purchased a strip of 10 tablets each of the five leading brands in one city, Kolhapur, India, of Telmisartan 40 milligram. The prices of the strip of 10 tablets of each of the five selected brands were compared. In turn the annual cost of each of these five, was compared directly as well as using percentages. The data was collected, analysed and presented.

Results: The data of the cost of the preparations of five different brands of a single antihypertensive drug, Temisartan 40 milligram shows that the annual cost of the costliest among the three brands of this drug is almost three times, that of the cheapest brand, or in other words almost 300 percent that of the cheapest brand.

Conclusions: the cost variation amongst the five brands was considerable. India being a country with a major chunk of the population being very price sensitive, the prescribing physician must select the brand carefully. The most costly preparation of Temisartan can significantly add to the burden on the patient's annual budget. Thus, Pharmacoeconomics must take an important place while prescribing medicines, especially in a country like India.
\end{abstract}

Keywords: Annual cost, Antihypertensives, Pharmacoeconomics, Temisartan 40 milligram

\section{INTRODUCTION}

Prevalence of hypertension in India is $29.8 \% .{ }^{1}$ Volume of sales puts India as the third globally, considering the annual sales. India is a manufacturing base for drugs, exporting medicines to many countries in the world. ${ }^{2}$ But at the same time this leads to a great price variation, likely when the government is unable to provide low cost medications to the people and they are forced to purchase such medications from the private sector. ${ }^{3}$ As antihypertensive drugs are to be taken lifelong, in almost all of the hypertensive patients, even a small price variation results in a huge economic burden on patients especially with those in lower socioeconomic status of the developing countries. In India, medical insurance being in its infantile stages, more than eighty percent of healthcare expenditure is paid by the patients.

In 1997, NPPA (National Pharmaceutical Pricing Authority) was established for ensuring availability and affordability of the drugs. The drug price control order (DPCO) 2013 is one such effort under NPPA. DPCO was 
implemented by the government with the aim of bringing down the cost of essential medicines. ${ }^{4}$

This study was undertaken to evaluate the cost variation in five different brands of the antihypertensive drug, Telmisartan 40 milligram.

\section{METHODS}

This study was conducted in Kolhapur city of India. Authors purchased strips of 10 tablets each of five leading, different brands of Temisartan 40 milligram from the local market. The price paid was the M.R.P. (Maximum Retail Price). All the five strips were recently manufactured, within last eight months. The five different brand strips were labeled as A, B, and C, D, E under the coding, to maintain the confidentiality of those brands. The price of the strips of 10 tablets of each brand were recorded under their specific code name.

This price was converted to the annual cost of each brand preparation for a single patient, based on once a day dosing prescription.

This data was analyzed in the form of direct cost, as well as in percentages. While calculating the percentages, the cost of the cheapest brand preparation was considered as 100 percent, while parentages

of all other preparations were worked out in comparison to the cheapest brand. The data was presented in the form of tables, bar diagrams for better visualization.

\section{Inclusion criteria}

Only those branded preparations, which were available commonly in the local market of Kolhapur city, at the time of the study were included. All of the included drugs were available for oral intake. Preparations containing only Temisartan 40 milligram were selected.

\section{Exclusion criteria}

Fixed dose combinations were excluded.

\section{Statistical methods}

Data was collected, prices of strips of 10 tablets of each of the five brands were noted. Based on this the cost of annual purchase of the preparations for a single patient was calculated and the cost comparisons were done directly and in percentages. The data was presented as bar diagrams and graphs, tables.

\section{RESULTS}

The present study was conducted in Kolhapur city, in Maharashtra state, India. The strips of ten tablets of each of the five leading brand preparations of Telmisartan 40 milligram, were purchased from the local market. All the brand preparations were recently manufactured. All the brand preparations were designated under the code names A, B, C, D and E. The cost for ten tablets, the cost per tablet, the annual cost to a single patient, based on single daily dosing were calculated in direct figures and in percentages. Thus, it is seen that brand $\mathrm{A}$ is the cheapest one while brand $\mathrm{C}$ is the costliest amongst all. The costs of the remaining brands i.e. brands $\mathrm{B}, \mathrm{D}$ and $\mathrm{E}$, fall in between. It is also seen that the costliest brand cost almost three times or 300 percent more than the cheapest brand.

Table 1 shows, the prices for 10 tablets as well as single tablet of each of the five brand preparations under the specified code names. Thus, it can be seen that the brand A provides the drug Telmisartan $40 \mathrm{mg}$, the cheapest, costing 32.65 rupees for 10 tablets, while costing 3.265 rupees for a single tablet. In contrast brand $\mathrm{C}$ is the costliest among all five, costing 103.91 rupees for 10 tablets and 10.39 rupees for single tablet. Amongst the remaining three brands, $\mathrm{B}, \mathrm{D}$ and $\mathrm{E}$ have costs in increasing order.

Table 1: The prices of a strip of 10 tablets of five different brands of Temisartan $40 \mathrm{mg}$.

\begin{tabular}{|lll|}
\hline Brand Code & $\begin{array}{l}\text { Price for } \mathbf{1 0} \text { tab } \\
\text { (rupee) }\end{array}$ & $\begin{array}{l}\text { Price of } \mathbf{1} \text { tab } \\
\text { (rupees) }\end{array}$ \\
\hline A. & 32.65 & 3.265 \\
\hline B. & 51.95 & 5.195 \\
\hline C. & 103.91 & 10.39 \\
\hline D. & 63 & 6.3 \\
\hline E. & 73.53 & 7.153 \\
\hline
\end{tabular}

Table 2 represents the annual cost of each of the five brand preparations, for a single patient, based on single daily dosing. Thus it can be observed that the cheapest, i.e. brand A costs 1192.72 rupees annually, for a single patient based on a single tablet once daily basis, while the costliest brand, i.e. brand C costs 3792.35 rupees for a single patient based on single tablet daily dosing. The cost difference between the cheapest and the costliest brand is more than three times. The remaining three brands viz, B, D, E fall in between as far as the annual cost is concerned, costing 1896.17 rupees, 2300.00 rupees, 2610.85 rupees respectively.

Table 2: Annual cost of Temisartan $40 \mathrm{mg}$ tablets to a single patient based on once daily dosing.

\begin{tabular}{|ll|}
\hline Brand & Annual cost (rupees) \\
\hline A. & 1191.72 \\
\hline B. & 1896.17 \\
\hline C. & 3792.35 \\
\hline D. & 2300.00 \\
\hline E. & 2610.85 \\
\hline
\end{tabular}

Table 3 presents the annual cost comparisons for a single patient, based on a single tablet once daily basis of all the five brands. This is presented in the form of percentages. 
Thus, it can be seen that the brand A, the cheapest amongst all five brands is considered to cost 100 percent. In this regard, the costliest brand, i.e. brand $\mathrm{C}$ costs 318.11 percent as compared to brand A. Remaining three brands cost as follows: 159 percent for brand B, 190 percent for brand D and 219 percent for brand $\mathrm{E}$.

Table 3: Comparison of the annual cost of five different brands of Telmisartan $40 \mathrm{mg}$. in percentage.

\begin{tabular}{|ll|}
\hline Brand & Comparative cost (percent) \\
\hline A. & 100 \\
\hline B. & 159 \\
\hline C. & 318.11 \\
\hline D. & 190 \\
\hline E. & 219 \\
\hline
\end{tabular}

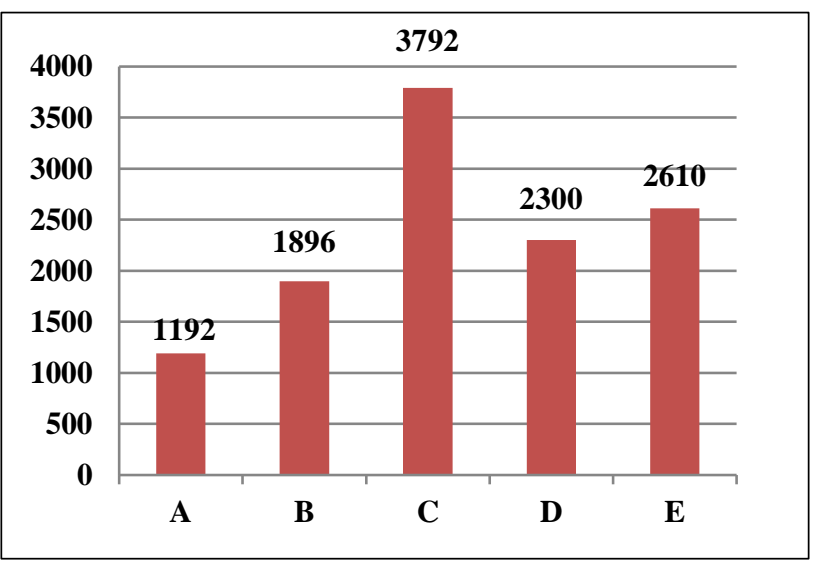

Figure 1: Annual cost of the five different brand preparations of Telmisartan $\mathbf{4 0}$ milligram for a single patient.

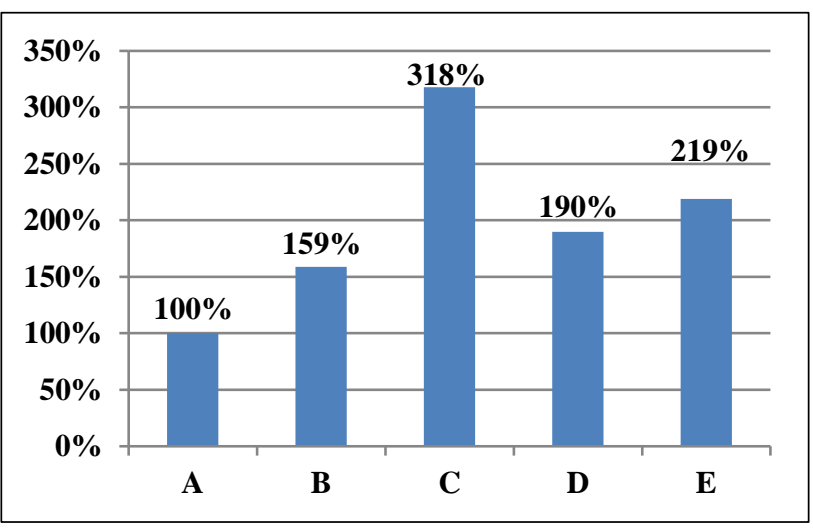

Figure 2: Comparison of the annual cost of five different brand preparations of Telmisartan 40 milligram, for a single patient.

Figure 1 depicts the annual cost of each of the five brand preparations, for a single patient, based on single tablet once daily dosing. Thus, it can be observed that the cheapest, i.e. brand A costs approximately 1192 rupees annually, for a single patient based on a single tablet daily basis, while the costliest brand, i.e. brand $\mathrm{C}$ costs approximately 3792 rupees for a single patient based on single tablet daily dosing. The cost difference between the cheapest and the costliest brand is more than three times. Remaining three brands viz B, D, E fall in between as far as the annual cost is concerned, costing annually 1896 rupees, 2300 rupees, 2610 rupees respectively.

Figure 2 depicts the annual cost comparisons for a single patient, based on a single tablet daily basis of all the five brands. This is presented in the form of percentages. Thus, it can be seen that the brand A, the cheapest amongst all five brands is considered to cost 100 percent. In this regard, the costliest brand, i.e. brand $\mathrm{C}$, costs 318 percent as compared to brand $\mathrm{A}$. Remaining three brands costs are as follows: 159 percent for brand B, 190 percent for brand $\mathrm{D}$ and 219 percent for brand $\mathrm{E}$.

\section{DISCUSSION}

Management of hypertension in Indian patients includes lifestyle modification, which in turn includes nutrition and dietary approaches, exercise, yoga and stress management. Drugs are prescribed to the carefully selected patients.

When the drug treatment is deemed necessary. The drug groups acting on the rennin and Angiotensin system are considered amongst the drugs of primary choice. This group of drugs include Angiotensin Converting Enzyme Inhibitors (ACEI) such as Enalapril and Angiotension receptor Blockers (ARB) such as Telmisartan. These are amongst the most commonly prescribed and popular antihypertensive drugs.

Profit margin of pharmaceutical companies is extremely variable, often ranging from $1000 \%$ to $4000 \% .^{5}$ In 1995 , the first Drug Price Control Order (DPCO-1995) was issued which included the prices of seventy six drugs under the price control. ${ }^{6}$ For the benefit of patients, government authorizes the NPPA to regulate prices of medicines which are included in the National List of Essential Medicines (NLEM) in 2013 i.e. 348 essential medicines. Government is making every effort for ensuring availability and affordability of medicines for all citizens of India. The order authorized the NPPA to regulate the medicine prices of not only NLEM but also medicines which are not listed in NLEM (non-NLEM). ${ }^{7}$ But even after these efforts there is a great price variation and some drug brand preparations still cost more than the other brands. Every pharmaceutical company desires to quote its own price of the medicines they manufacture without hampering their profit margin. ${ }^{8}$ In USA there is no strict price regulation and thus the drug companies are willing to invest more on research and development. $^{9}$

But for the sake of society there must be a surveillance system. This is even more relevant in India as there is no well-defined social security system. In addition medical insurance coverage is very poor and most of the healthrelated expenses are borne by the patients themselves. About 39 million Indians are facing grave financial burden 
every year due to rising health care costs and $30 \%$ patients die at home following discharge against medical advice from the intensive care units due to non-affordability of treatment. ${ }^{10}$

In the present study the annual cost of Temisartan $40 \mathrm{mg}$ for a single patient varies between 100 percent to 300 percent between the cheapest and the costliest brand amongst those selected for this study. Thus, while prescribing Temisartan $40 \mathrm{mg}$ to the patient, the Pharmaco economics of this drug must be considered. Prescribing costlier brand preparations, without justifiable reason for not so affording patients must be discouraged, especially in a country like India.

Thus, it might be stated that every physician must work on pharmaco economics of drugs, especially for conditions like hypertension, where drug treatment might be required for years together, and perhaps for life.

\section{CONCLUSION}

Large number of brands of Telmisartan $40 \mathrm{mg}$ are available in the market. Pricing of medicines is a very crucial issue and it has direct economic implications on patients resulting into poor compliance to treatment. Beside price control it is also very necessary to monitor manufacturing of drug under GMP (good manufacturing practice) to ensure quality of medicine. It is the moral responsibility of all medical professionals that cost effectiveness of drugs should be evaluated before prescribing it to any patients.

Funding: No funding sources

Conflict of interest: None declared

Ethical approval: The study was approved by the Institutional Ethics Committee

\section{REFERENCES}

1. Anchala R, Kannuri NK, Pant H, Khan H, Franco OH, Angelantonio ED, et al. Hypertension in India: a systematic review and meta-analysis of prevalence, awareness, and control of hypertension. J Hypertens. 2014;32(6):1170-7.
2. Banerji A. Review of Asia-Pacific's healthcare systems with emphasis on the role of generic pharmaceuticals. Academy of Health Care Management J. 2013;9(1/2):53A.

3. Kotwani A, Ewen M, Dey D, Iyer S, Lakshmi PK, Patel A, et al. Prices and availability of common medicines at six sites in India using a standard methodology. Indian J Med Res. 2007;125(5):645-54.

4. DPCO, Drug Price Control Order 2013 - National Pharmaceutical Pricing Authority; 2013. Available at: http://www.arthapedia.in

5. Ahmad A, Patel I, Sanyal S, Balkrishnan R, Mohanta GP. Availability, cost and affordability of antimalarial medicines in India. Int J Pharm Clin Res. 2014;6(1):712.

6. Harvard School of Public Health, Boston, MA, USA. How Effective Is India's Drug Price Control Regime? 2007. Available at: https://cdn1.sph.harvard.edu/wpcontent/uploads/sites/114/2012/10/RP256.pdf.

7. Sahay A, Jaikumar S. Does pharmaceutical price regulation result in greater access to essential medicines? Study of the impact of drug price control order on sales volume of drugs in India. Research and publication of Indian Institute of management, Ahmadabad. W.P.2016-02-01, Jan 2016;1-28.

8. DPCO Impact: Pharma cos growth suffers for drugs under price ceiling/ Business Standard News, 2013. Available at: https://www.businessstandard.com/article/companies/dpco-impactpharma-cos-growth-suffers-for-drugs-under-priceceiling-113081800677_1.html.

9. Vernon, John A, Golec JH, and Hughen WK. The Economics of Pharmaceutical Price Regulation and Importation: Refocusing the Debate. Amer J Law Medi. 2006;32(2-3):175-92.

10. Balarajan Y, Selvaraj S, Subramanian SV. Health care and equity in India. Lancet. 2011;377(9764):505-15.

Cite this article as: Rajadnya VA, Bedi SR. Cost comparisons of five leading brands of the antihypertensive drug, Telmisartan, available in an Indian city. Int J Basic Clin Pharmacol 2019;8:137780 . 